\title{
Integration of geophysical and geomechanical data to understand the depletion of the Marlim field, Campos Basin
}

Integração de dados de geofísica e geomecânica para entendimento da depleção do campo de Marlim, Bacia de Campos

\author{
Larissa Furtado Torres ${ }^{1}$ (D), Emílio Velloso Barroso ${ }^{1}$ (D) \\ ${ }^{1}$ Universidade Federal do Rio de Janeiro - UFRJ, Instituto de Geociências, Departamento de Geologia, Av. Athos da Silveira \\ Ramos, 274, CEP 21941-916, Rio de Janeiro, RJ, BR (larissa.torres@ufrj.br; emilio@geologia.ufrj.br)
}

Received on February 20, 2020; accepted on December 15, 2020

\begin{abstract}
Located in the Campos Basin, Brazil, the Marlim field, consists of two turbidite systems deposited during eustatic sea-level variations in the Oligocene/Miocene. The reservoir was discovered in 1985, and its production started to decline in 2002. One of the techniques selected to assist in the recovery of oil from the reservoir was the 4D seismic. However, its interpretation can be complex. In order to help address this issue, the present study proposed an analysis of the depletion of a small field area from 1997 to 2010, combining geophysical (4D seismic) and geomechanical (pore pressure) data through the construction of pore pressure $3 \mathrm{D}$ models for both years, which can be subtracted and compared to seismic anomalies. The results obtained were: an average depletion of $0.42 \mathrm{ppg}\left(50.33 \mathrm{~kg} / \mathrm{m}^{3}\right)$ of pore pressure gradient in the field; the identification of potential fluid-flow barriers, such as an NW-SE-oriented channel and sealing faults; and the detection of two areas with an expressive presence of 4D seismic anomalies, one of them showing a quite evident difference between pore pressure gradients, suggesting field depletion. The use of very old and noisy seismic data hindered the application of this methodology. Nevertheless, this research demonstrated the relevance of estimating pore pressure in the reservoir and how this geomechanical parameter can be useful in assessing the level of field depletion.
\end{abstract}

Keywords: Reservoir; 4D seismic; Pore pressure.

\section{Resumo}

O campo de Marlim, situado na Bacia de Campos, Brasil, é constituído de dois sistemas turbidíticos depositados durante variações do nível eustático do mar no Oligoceno/Mioceno. O reservatório foi descoberto em 1985 e a sua produção começou a declinar em 2002. Uma das técnicas selecionadas para auxiliar na recuperação de óleo do reservatório foi a sísmica 4D, apesar de ela ser de difícil intepretação. Com o objetivo de auxiliar nessa problemática, o presente trabalho propôs uma análise da depleção de uma pequena área do campo no período de 1997 a 2010, combinando dados geofísicos (sísmica 4D) e geomecânicos (pressão de poros) por meio da construção de modelos 3D de pressão de poros para ambos os anos, que possam ser subtraídos e comparados às anomalias sísmicas. Como resultados obtidos, têm-se: uma depleção média de 0,42 ppg $(50,33 \mathrm{~kg} / \mathrm{m} 3)$ do gradiente de poro pressão para o campo; a identificação de possíveis barreiras de fluxo de fluidos, como um canal de direção NW-SE e falhas selantes; e a identificação de duas áreas com maior presença de anomalias sísmicas 4D, uma delas mostrando uma diferença bastante evidente entre os gradientes de pressão de poros, sugerindo a depleção do campo. A utilização de dados sísmicos bastante antigos e ruidosos trouxe dificuldades na aplicação dessa metodologia. Ainda assim, os resultados desta pesquisa demonstraram a relevância da estimativa da pressão de poros no reservatório e como esse parâmetro geomecânico pode ser útil para acessar o grau de depleção do campo.

Palavras-chave: Reservatório; Sísmica 4D; Pressão de poros. 


\section{INTRODUCTION}

The Marlim field is located in the Campos Basin, about $150 \mathrm{~km}$ from the coast of the city of Macaé, Rio de Janeiro, Brazil. The reservoir has its deposition associated with eustatic sea-level variations during the Oligocene/Miocene, responsible for forming the two main systems of turbidity flows (Figure 1) found in the field (Souza et al., 1989; Pinto et al., 2001; Oliveira et al., 2007; Pelisman and Vincentelli, 2017). It consists of a succession of amalgamated lobes and presents medium-to-fine sandstone facies, with low silt $(<10 \%)$ and clay $(<2 \%)$ content, poorly consolidated,

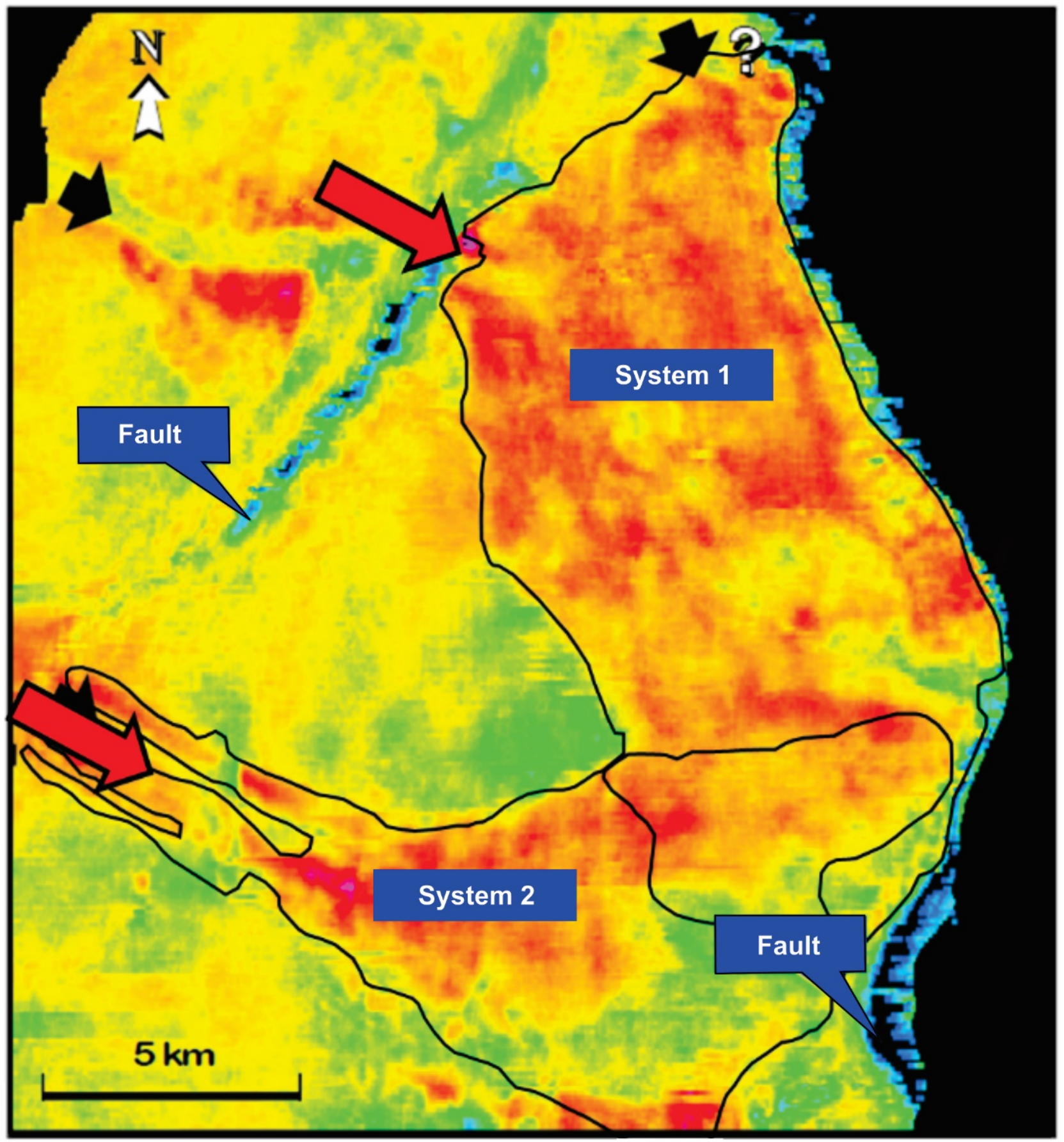

Figure 1. Seismic impedance map of the Marlim reservoir, indicating both turbidite systems identified. Orange and red colors represent thicker sandstones. Modified from Pinto et al. (2001) and Oliveira et al. (2007). 
and with excellent porosity (Lorenzatto et al., 2004; Johann et al., 2006; Oliveira, 2008).

The field was one of the greatest discoveries of Petrobras in the 1980s, starting its production in 1991, which continues to the present day. The reservoir had an original pressure of $287 \mathrm{kgf} / \mathrm{cm}^{2}(4,082 \mathrm{psi})$, and in 1994, water injection started to maintain the pressure and increase field recovery (Sansonowski and Macbeth, 2008).

Marlim can be considered a mature field since it reached its production peak in 2002, with a decline after this year (Duarte, 2003). As a result, the use of techniques to increase the recovery factor in the field became common (Denney, 2012).

The 4D seismic is a technique widely used in the oil industry for this application, consisting of repeating a 3D survey in a given time interval (Triggia et al., 2001). However, interpreting the anomalies observed in the 4D seismic may not be easy, as these anomalies can be induced by changes in pressure and saturation, and both have the same impact on the difference of seismic amplitudes (Nunes et al., 2009).

In an attempt to separate the effects produced by pore pressure variations, the present study analyzed the depletion of a small area of the Marlim field from 1997 to 2010 , combining seismic and modeled pore pressure data. The identification of depleted field regions is associated with abnormally low pore pressure gradients due to production. We underline that, in the oil and gas industry, detecting abnormally high pore pressure gradients is an activity of great interest for projects and the safe construction of wells (Picolini and Chang, 2019; Zhang et al., 2020).

The type of evaluation presented in this article assumes great relevance today, given the entry, in recent years, of new operators and the need to optimize mature fields (Bampi and Costa, 2010) of turbidite origin in the post-salt sequence of the Campos Basin.

\section{DATA AND METHODOLOGY}

This study used 2 3D seismic volumes and 11 wells from the Marlim field, both provided by the Brazilian National Agency of Petroleum, Natural Gas and Biofuels (Agência Nacional do Petróleo, Gás Natural e Biocombustíveis ANP) and within an area of approximately $50 \mathrm{~km}^{2}$ of the field (Figure 2).

The seismic volumes used were:

- a 1997 acquisition, with azimuth $123^{\circ}$ and good resolution, but very noisy (Johann et al., 2006; Johann et al., 2009);

- a 2010 acquisition that has not yet been mentioned in previous articles.
However, the volumes were in different domains: the first in the time domain and the second in the depth domain. As to other data, caliper profiles, gamma rays, resistivity, transit time, density, neutron, lithology, and direct pressure measures (pre-test) were provided.

The methodology employed was divided into three phases (Figure 3):

- data preparation and interpretation;

- construction of 3D pore pressure gradient models;

- creation of the 4D seismic difference volume.

Of note, pore pressure gradient is the relationship between pore pressure and depth. This parameter is widely used in the industry because it allows a direct comparison with the specific mass of the drilling fluid. Consequently, the pore pressure gradient has a specific weight unit, commonly called equivalent fluid weight or equivalent density. Another advantage of using pore pressure gradient instead of absolute pressure is that the first is constant for hydrostatic pressures and fluids of known composition, regardless of depth. The industry often uses the pound per gallon (ppg) unit (Rocha and Azevedo, 2009), adopted, in this article, with equivalent values in the international system $\left(\mathrm{kg} / \mathrm{m}^{3}\right)$, presented in parentheses.

\section{Phase 1: data preparation and interpretation}

Phase 1 involved creating the database with information provided by the ANP and interpreting the data necessary for phases 2 and 3.

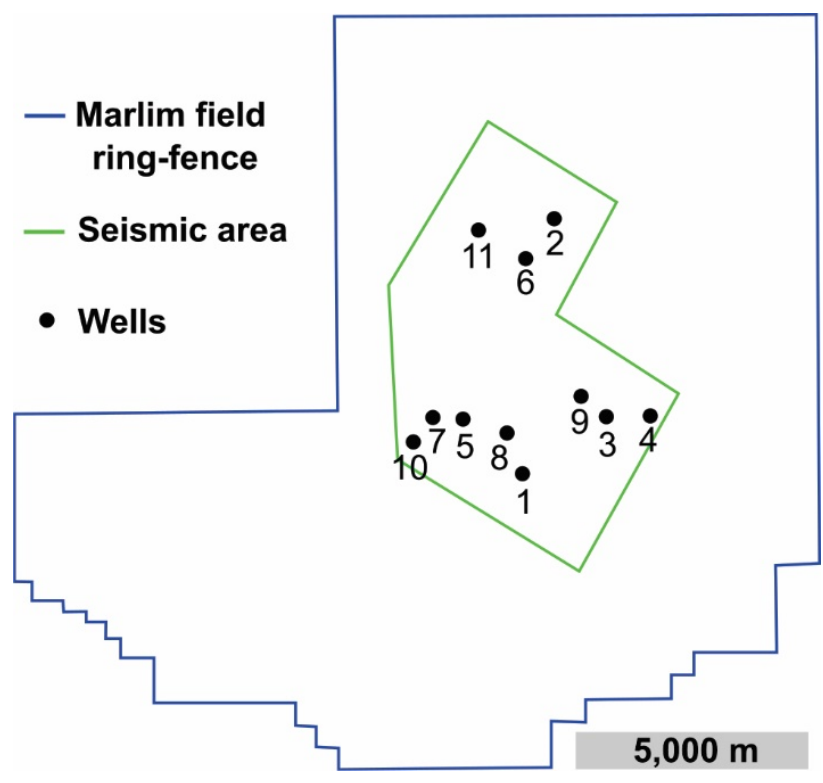

Figure 2. Location of the study area (green polygon) and the wells (gray dots) within the ring-fence of the Marlin field (blue polygon). 
In this stage, we started to interpret horizons and faults. We mapped the seafloor and six horizons of easy seismic identification (horizons 1, 2, 3, 4, 5, and 6), the top and bottom of the reservoir (Figure 4), and the sea level. Faults have been mapped only within the range of the reservoir (Figure 4).

After these interpretations, a well-to-seismic tie was performed for the 1997 time-domain (Figure 4). The wellto-seismic tie for the 1997 volume used the check-shot of well 1 (the only one available), as well as transit time and density profile data. Based on this information, we calculated reflection coefficients convolved by waveforms extracted from seismic data. These steps of the work method produced synthetic seismic data for the wells and seismic horizons assessed, besides markers for the seafloor and the top and bottom of the reservoir, which were used as references. The process resulted in time-depth tables, which,

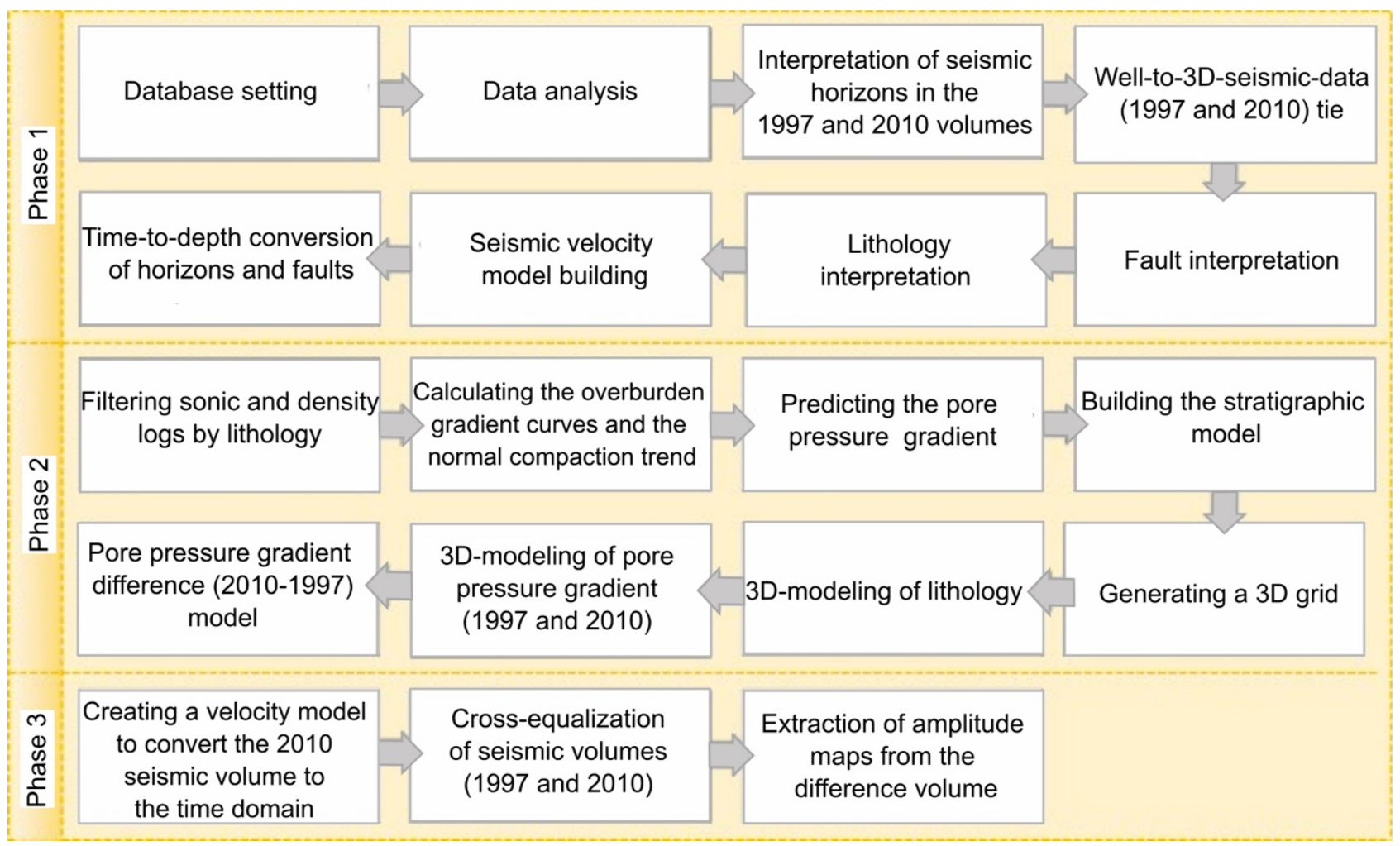

Figure 3. Flowchart with a simplified version of the methodology applied in this study.

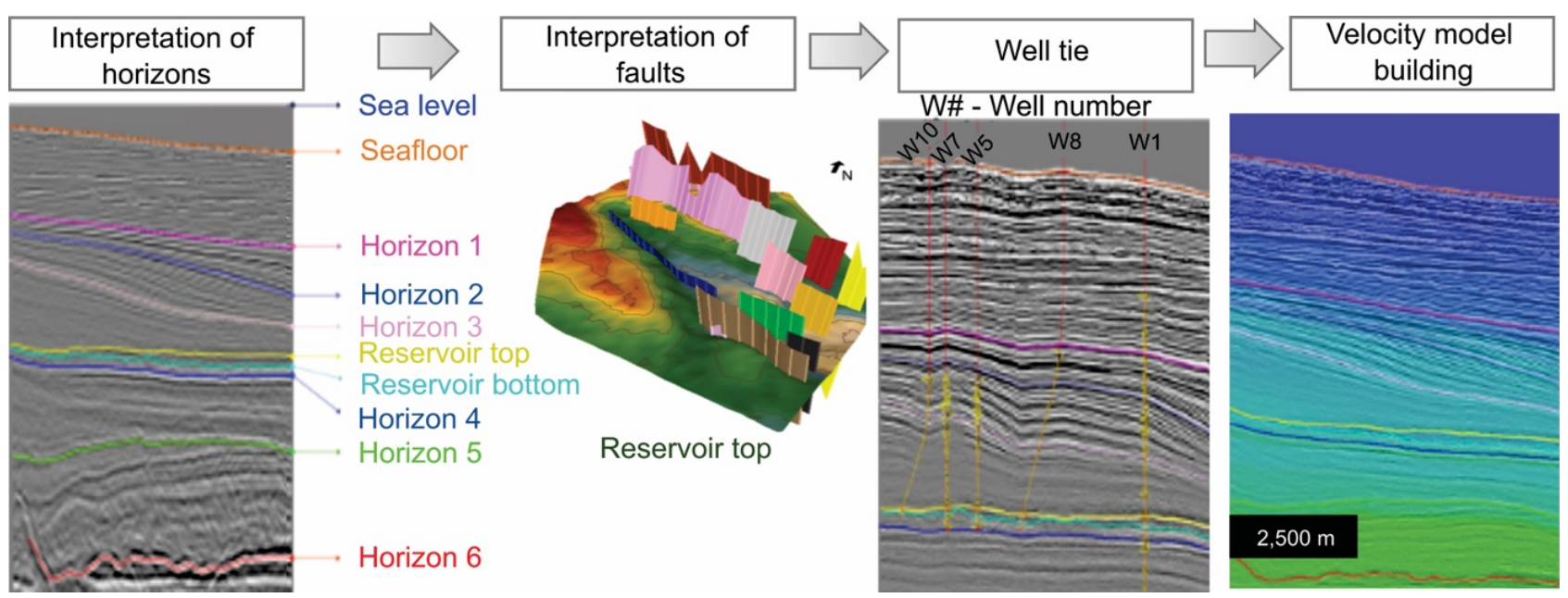

Figure 4. Workflow sequence containing: the horizons interpreted in different intervals, the faults interpreted for the reservoir, the well-to-seismic tie, and the velocity model created. 
together with the horizons, enabled creating a velocity model. This model was used to convert the horizons and faults analyzed from the time domain to the depth domain. This conversion allowed using the data to construct the $3 \mathrm{D}$ grid in the next phase.

Lithology interpretation also became necessary since the information was not available for some wells. Its analysis was based on gamma-ray profiles, density, neutron, resistivity, and transit time. The caliper profile was adopted as quality control for other profiles.

This stage ended with a density curve analysis and editing, given its extreme importance for overburden gradient calculation and, consequently, for the estimation of pore pressure of low-permeable rocks. For intervals without this information, two techniques were applied to calculate density: the method by Gardner et al. (1974) and the correlation between vertical depth and density. The formula by Gardner et al. (1974) (Equation 1) calculates density using transit time and two empirical constants $-a$ and $b$. For the constant $a$, we tested the values $0.230,0.234$, and 0.237 - the last one was chosen for better adjusting the curve to the shale density (Figure 5), as this rock is prevalent in intervals lacking data. For the constant $b$, we used the value 0.25 .

$\rho_{b}=a \times\left(\frac{10^{6}}{\Delta t}\right)^{b}$

In which:

- $\rho_{b}$ total density of the formation $\left(\mathrm{g} / \mathrm{cm}^{3}\right)$;

- $\Delta \mathrm{t}=$ transit time $(\mu \mathrm{s} / \mathrm{ft})$;

- $a$ and $b=$ empirical constants.

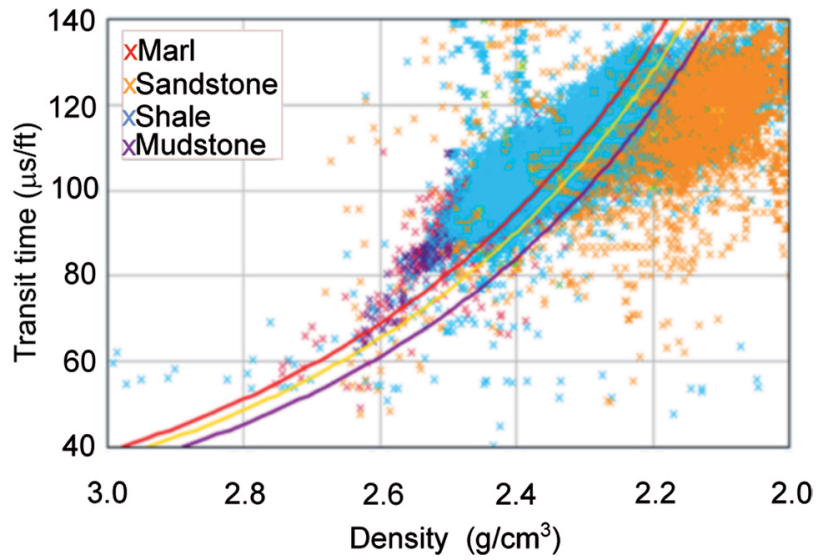

Figure 5. Density chart $\times$ transit time, colored by lithology, to observe the data relationship. For the regression, we adopted the formula by Gardner et al. (1974), using different values for the constant $a: 0.23$ (purple regression), 0.234 (yellow regression), and 0.237 (red regression).
Since some intervals still lacked density data after the technique was applied, we created a correlation between vertical depth and density. The line obtained was used to calculate the density of the missing intervals. For seawater, we adopted the value $1.03 \mathrm{~g} / \mathrm{cm}^{3}$.

\section{Phase 2: construction of 3D pore pressure models}

Non-reservoir rock pore pressure was calculated by the Eaton (1972, 1975) method, using transit time (Equation 2), associated with the adaptation by Rocha and Azevedo (2009), who suggest adopting exponent 2 for Brazil. To that end, we calculated, in parallel, overburden gradients, the normal pore pressure gradient, and the normal transit-time line; the last one was obtained by the correlation between transit time and the true vertical depth. After concluding these steps, pore pressure was calculated for non-reservoir rocks. Reservoir rock pore pressure was obtained directly from pre-tests after well drilling.

$G_{P}=G_{O V}-\left[\left(G_{O V}-G_{N}\right) \times\left(\frac{\Delta t_{N}}{\Delta t_{O}}\right)^{3,0}\right]$

In which:

- $\mathrm{G}_{\mathrm{p}}=$ pore pressure gradient ( $\left.\mathrm{psi} / \mathrm{ft}\right)$;

- $\mathrm{G}_{\mathrm{N}}=$ normal pore pressure gradient (psi/ft);

- $\mathrm{G}_{\mathrm{OV}}=$ overburden gradient (psi/ft);

- $\Delta \mathrm{t}_{\mathrm{O}}=$ transit time observed $(\mu \mathrm{s} / \mathrm{ft}) ;$

- $\Delta \mathrm{t}_{\mathrm{N}}=$ value of the normal transit-time line $(\mu \mathrm{s} / \mathrm{ft})$;

- $3.0=$ exponent identified for the sonic profile of the Gulf of Mexico.

Following the pore pressure calculation for the wells, we constructed the 3D models, whose steps consisted of creating a 3D grid, upscaling well data, generating the facies proportion curve and map, elaborating variograms, simulating facies properties, and, lastly, simulating the pore pressure for 1997 and 2010.

The 3D grid was created between the sea level and the bottom of the reservoir, resulting in six intervals. Its cells were generated with varying thickness, having lower refinement in the sea level direction (average thickness of $49 \mathrm{~m}$ ) and greater refinement in the reservoir direction $\left(6^{\text {th }}\right.$ grid interval), whose average thickness was $2 \mathrm{~m}$. Well data was upscaled by geostatistical methods. In order to define the facies, the parameter adopted was the most frequent facies, with the more continuous one prevailing in the event of a tie. For pore pressure data, we used arithmetic averages. Subsequently, facies vertical proportion curves were constructed, representing the input for the proportion map.

Facies simulation was conducted by the sequential indicator simulation method, based on variograms, with the facies proportion map as the secondary method. For the pore pressure models, the wells were divided into two groups - one 
for the 1997 model (wells 1 to 7) and another for the 2010 model (wells 8 to 11 ). The property was subject to the facies and distributed by sequential Gaussian simulation. For the interval 6 (reservoir), the parameters used for property distribution followed an $\mathrm{N} 57^{\circ} \mathrm{W}$ rotation, which is an approximation of the turbidite system deposition direction (Figure 1), indicated by Pinto et al. (2001), and anisotropy of 2. Anisotropy was not defined for the remaining intervals.

After obtaining the models, the difference between them (2010 model - 1997 model) was calculated to create the pore pressure difference model.

\section{Phase 3: creation of the 4D seismic difference volume}

In order to subtract the seismic volumes, both of them needed to be in the same domain and have the same amplitude scale. Thus, a velocity and cross-equalization model was created between the baseline (1997) and monitor (2010) seismic volumes.

The creation of the velocity model used mapped time and depth horizons, calculating the relationship between the average velocities for the interval. This model aimed to allow converting the 2010 seismic volume to the time domain. The cross-equalization between volumes was performed by balancing volume amplitudes, adjusting the spectra, calculating the time shift between volumes, and applying the time shift calculated in the monitor volume, which allowed the seismic volumes to have similar scales.

At the end of the procedures, the difference volume was calculated by subtracting the 1997 volume from the 2010 volume (2010 - 1997).

\section{RESULTS AND DISCUSSION}

Although we created models for the entire well range, we considered only the reservoir results (interval 6) since its pressure variations are the objects of study of this work.

Initially, we performed the quality control of the pore pressure difference model and the 4D seismic anomalies. In the first, the values obtained in the models were consistent with data from direct well measurement, resulting in the reliability of the model, as the mean variation between the direct well measures from 1997 and 2010 was -0.40 ppg $\left(-47.93 \mathrm{~kg} / \mathrm{m}^{3}\right)$, and the mean pore pressure difference in the model was $-0,42 \mathrm{ppg}\left(-50.33 \mathrm{~kg} / \mathrm{m}^{3}\right)$.

The quality control of 4D anomalies was conducted by visual analysis of lateral continuity and geological elements (channels and faults, for example) in sections and maps. We noted that the volume presented very discontinuous amplitude differences, probably due to the high level of noise in the 1997 seismic volume, which led to the maps generated having a poor aspect.
In order to compare the model with the 4D seismic and understand the field depletion, we extracted root mean square (RMS) amplitude maps using a central window of $30 \mathrm{~ms}$ in the horizon.

Based on map observation, we identified an NW-SEoriented feature interpreted as a channel, whose geometry can be evidenced by the different impacts that originated the bottom (narrower) and top (wider) of the reservoir (Figure 6).

Analyzing the same region in two sections of the pore pressure difference model, one perpendicular and another parallel to the main axis of the channel, we noted that they have, on many levels, values close to 0 (Figure 7), which can indicate the non-communication of the channel with the remainder of the reservoir.

Another comparison was performed with the results obtained by Sansonowski et al. (2007), who used the 1997 seismic volume as a baseline and a 2005 acquisition as a monitor. They obtained the difference volume based on those data, from which they could extract seismic anomaly bodies. Of note, the anomalies observed herein, although more discontinuous, are generally consistent with those observed in the 2007 study (Figure 8). We found the same absence of anomalies in the NW-SE channel region (dotted white polygon), as well as similar anomalies both in the southern and the N-NE part of the area.

The comparison with the pore pressure difference model revealed that the most depleted wells (wells 2, 3, 4, and 9Figure 9) were located in one of the regions identified as north-northeast anomalies (Figure 8).

Also in Figure 9, the pore pressure gradient difference model clearly has negative values (last column of the figure), indicating a pore pressure reduction in depths where the reservoir is located. As can be noted in the color scale associated with gradient differences, the productionrelated depletion is different in the surroundings of each well listed in the figure and seems to reflect the sedimentary heterogeneity of these reservoirs. Well 2 in specific (producer, drilled in 1991) showed no significant variation in the seismic amplitude model. The pore pressure gradient variation model presented signs of reduction in pore pressure, which may be related to the fact that water injection to maintain the static reservoir pressure started only in 1994, suggesting some depletion prior to the 1997 seismic acquisition.

Wells 3 and 4 have regular seismic anomalies, but the latter stands out as to pore pressure gradient variation. Records of this well describe it as a directional well, which may have favored the production. However, the lack of a production curve for these wells prevents a more detailed analysis. With respect to well 9, pre-test data indicated pressure drop compared to the initial level of the field, confirming the variations found in seismic amplitude models and the reduced pore pressure gradient. 


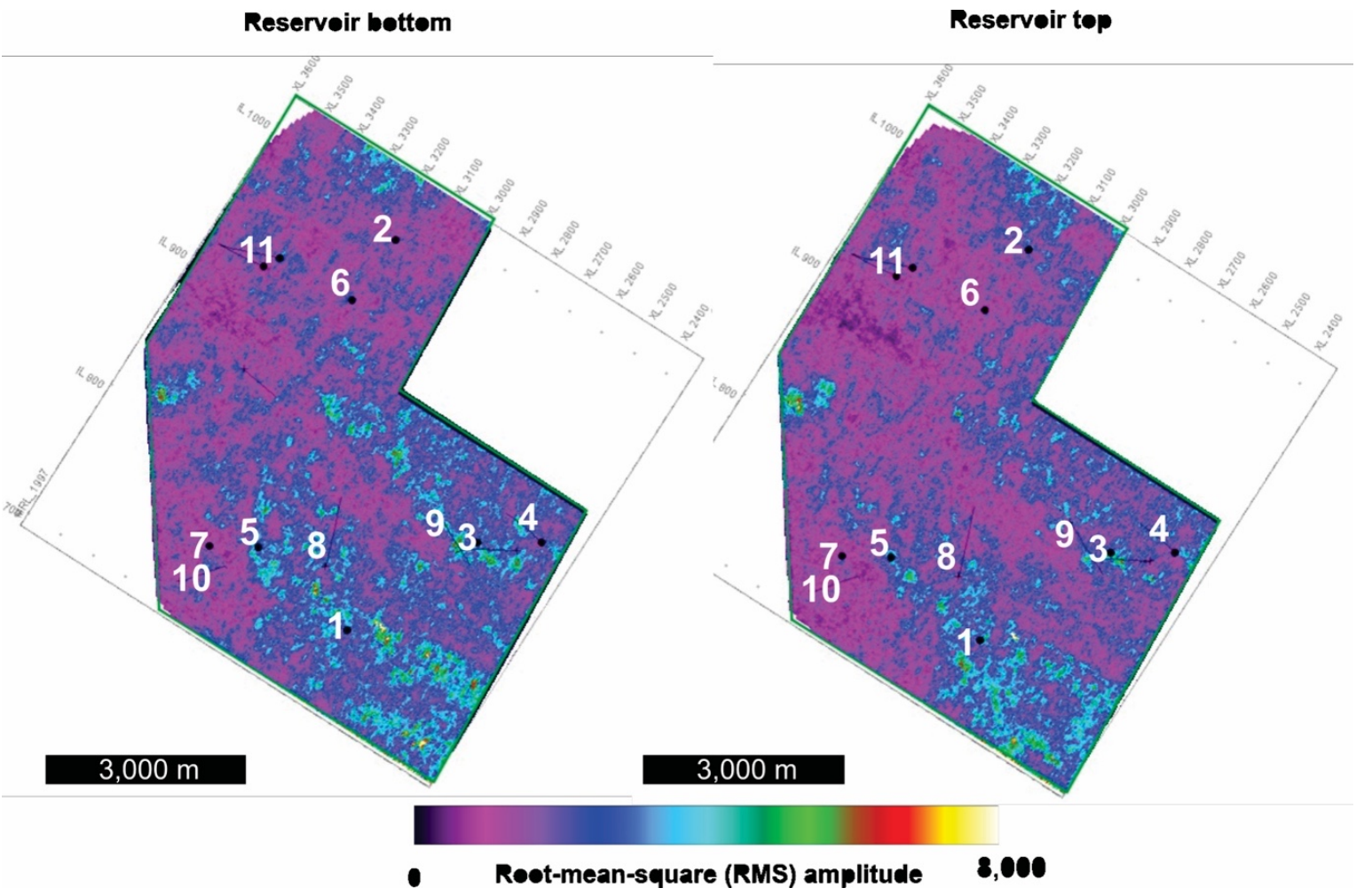

Figure 6. Root mean square amplitude maps of the top and bottom of the reservoir, extracted from the difference volume, with polygons (white dots) indicating the presence of an NW-SE-oriented channel.

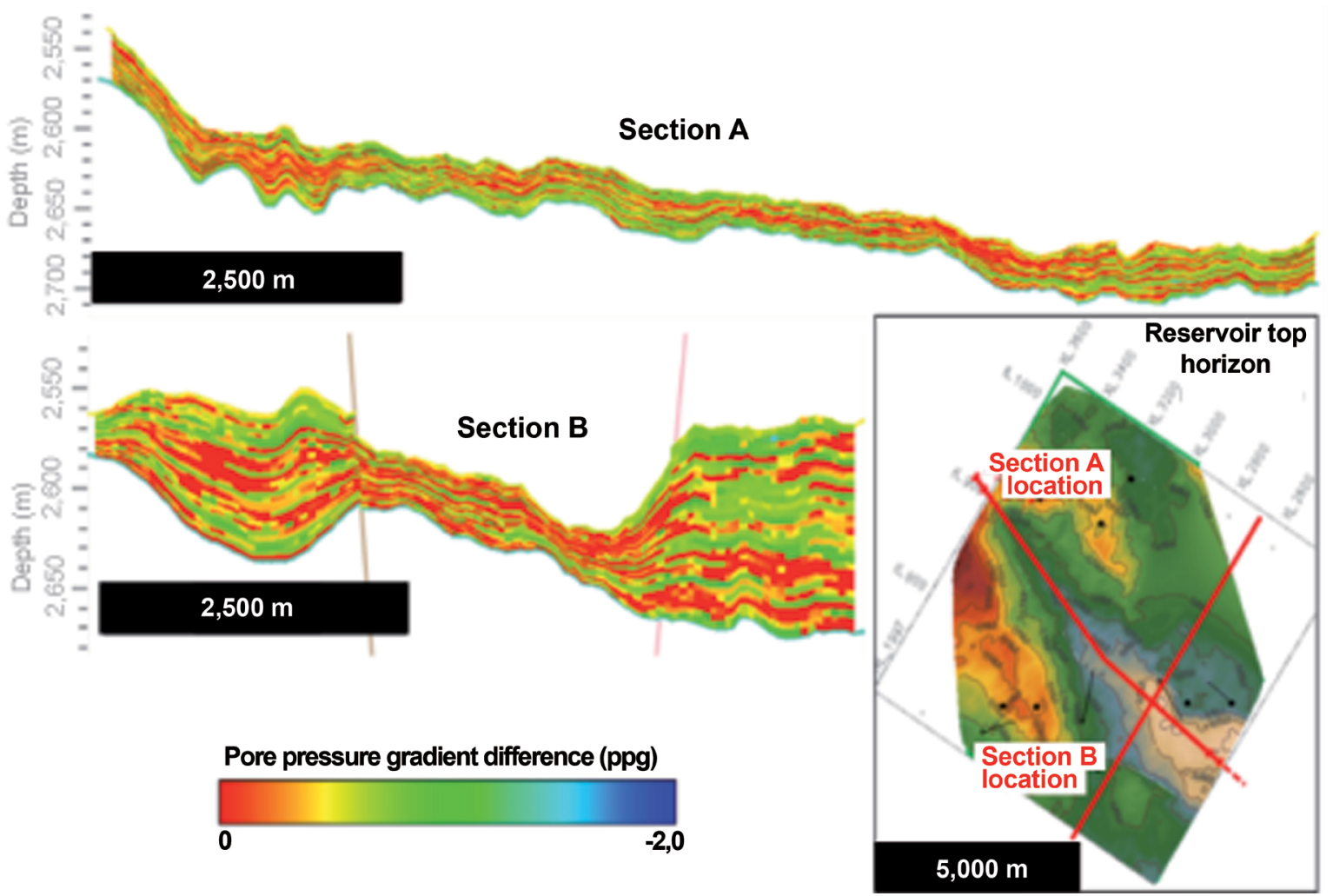

Figure 7. Sections crossing the main axis and the axis perpendicular to the NW-SE-oriented channel, showing the modeled pore pressure differences. 
Amplitude maps and fault polygons that intersect the horizons of the top and bottom of the reservoir were used to identify the characteristics of the barrier or conduit for fluid flow. We detected three faults that seemed to control the position and orientation of the channel and, at the same time, had a barrier aspect, as they partitioned the reservoir with very distinct seismic amplitudes (Figure 10). Nonetheless, the existence of these compartments was not observed in the pore pressure difference model since the distribution of pore pressure property was conditioned only by previously simulated facies.

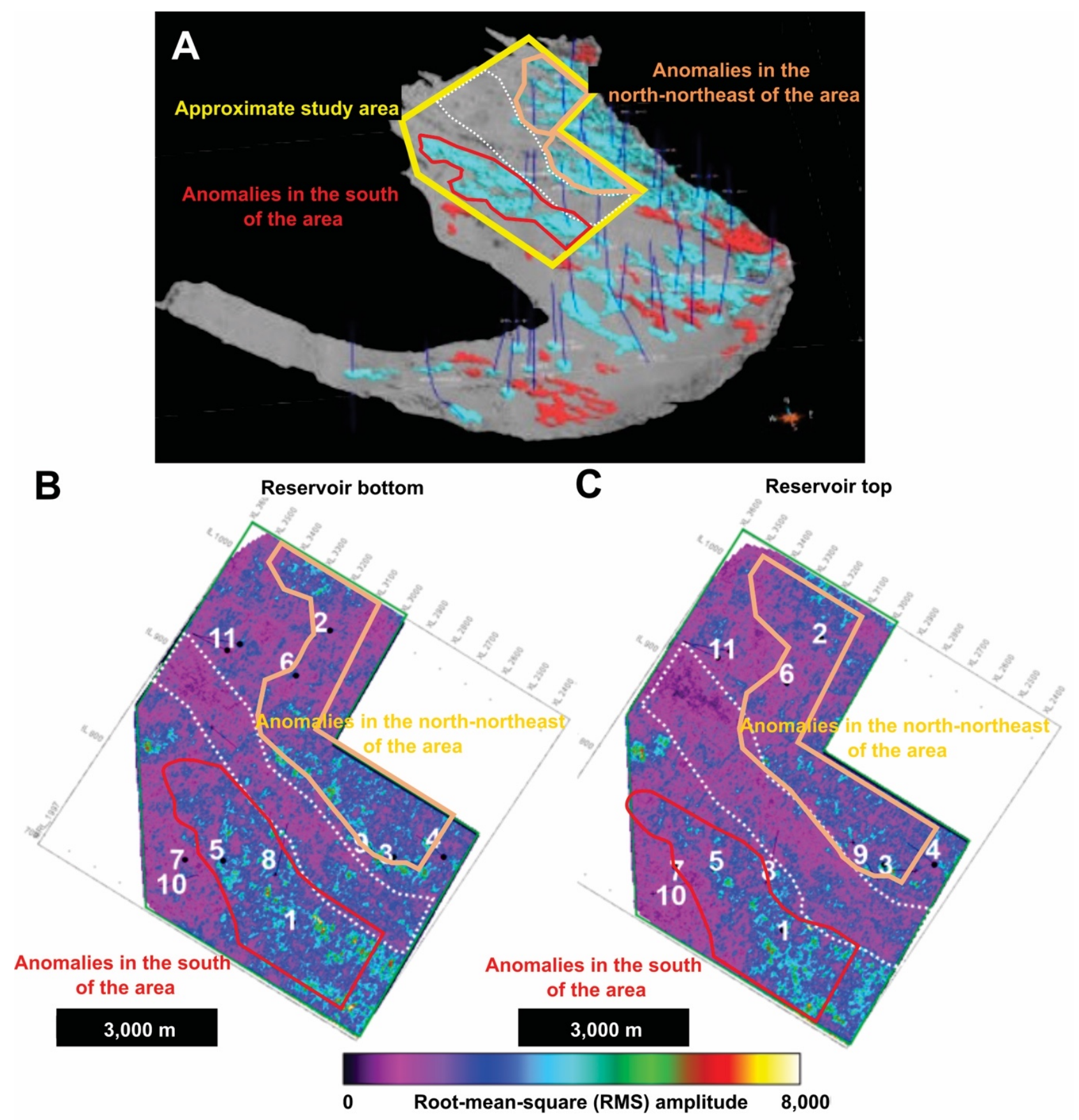

Figure 8. Comparison between 4D seismic results: (A) seismic anomaly bodies from Sansonowski et al. (2007) and $(B$ and $C$ ) amplitude maps of the present study, all indicating the same anomalies in the southern and N-NE part of the study area, as well as the absence of anomalies in the region of the NW-SE channel. 


\begin{tabular}{|c|c|c|c|c|}
\hline Well & Drilling year & $\begin{array}{c}\text { Well } \\
\text { classification } \\
\end{array}$ & $\begin{array}{c}\text { 4D-seismic } \\
\text { anomaly }\end{array}$ & $\begin{array}{c}\text { Anomaly in the pore } \\
\text { pressure gradient model }\end{array}$ \\
\hline 2 & 1991 & Producer & $\begin{array}{l}\text { Small variation } \\
\text { ineterey }\end{array}$ & High variation \\
\hline 3 & 1992 & Producer & Regular variation & Variations in some levels \\
\hline 4 & 1992 & Producer & Regular variation & High variation \\
\hline 9 & 2000 & Special & Noticeable variation & Variations in some levels \\
\hline
\end{tabular}

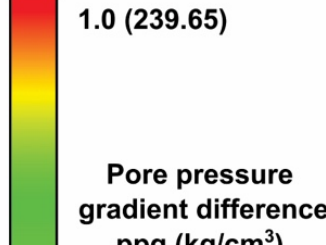

$\operatorname{ppg}\left(\mathrm{kg} / \mathrm{cm}^{3}\right)$

$-1.0(-239.65)$

17,000

Amplitude

difference

$-17,000$

Figure 9. Synthesis of information from wells 2, 3, 4, and 9 according to drilling year, classification (purpose), 4D seismic anomalies, and the pore pressure difference model.

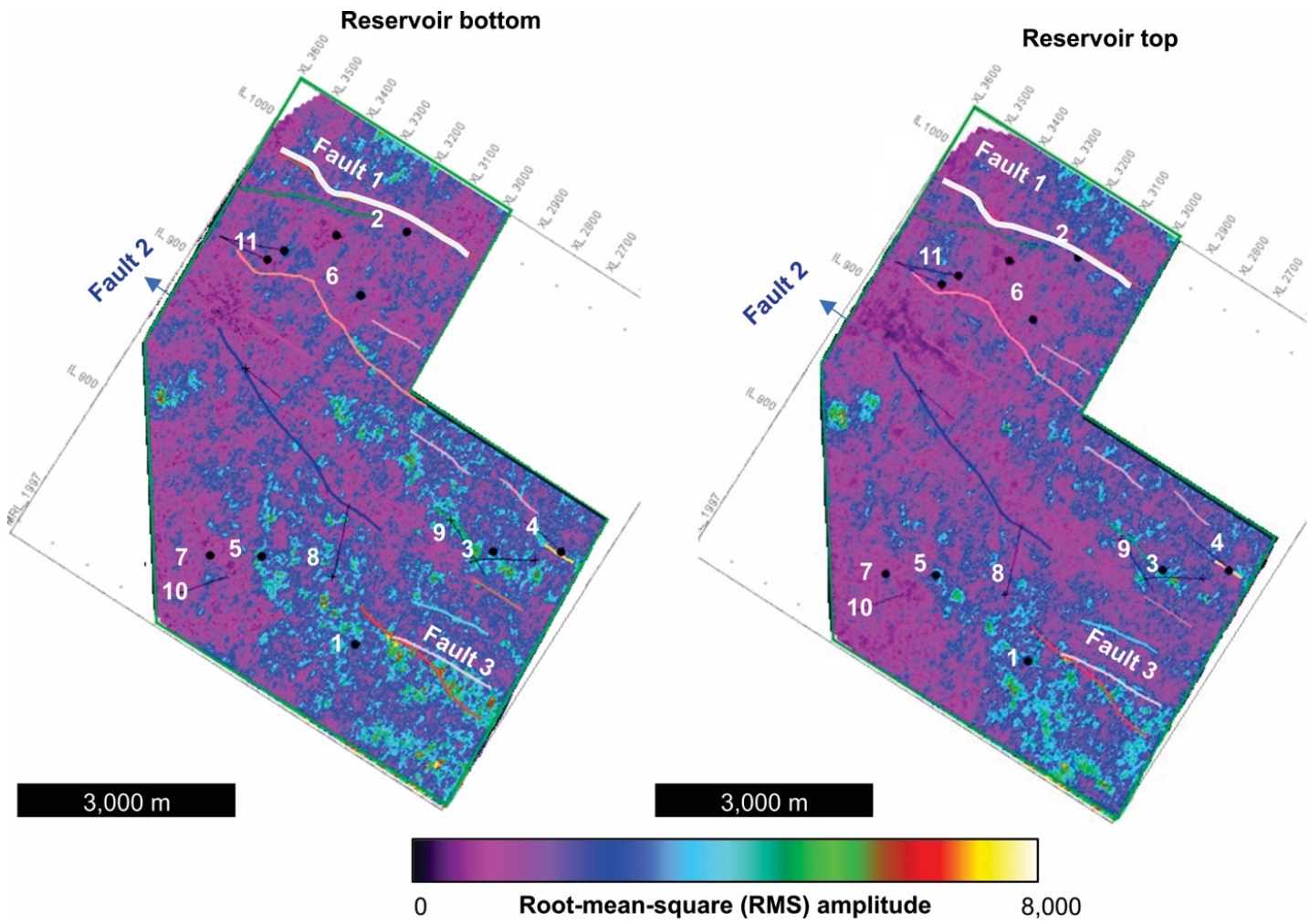

Figure 10. Maps of the top and bottom of the reservoir with fault polygons intersecting each horizon. The analysis indicates that the faults identified as 1,2 , and 3 may represent flow barriers. 


\section{CONCLUSIONS}

The workflow presented in this article has proven to fulfill the research on pore pressure gradient variation in different periods of continuous production in the Marlim field, even with noisy input data and limitations in the number of wells available for the study. In this regard, we emphasize that we made simplifications to construct the model, such as using pressure from a well drilled in 1991 for the 1997 model. Some limitations found in the data set, including the high level of noise in the 1997 seismic volume and the impossibility of defining fault transmissibility in the 3D model, hindered, respectively, the 4D seismic result and the chance of reproducing pressure compartments created by post-sedimentary deposition faults. Nevertheless, the combined analysis of these data with the 4D seismic allowed identifying flow barriers, possibly represented by three sealing faults, as well as delimiting an NW-SE-oriented channel and two regions with higher pressure variations (an anomaly area in the south and another in the north-northeast), with depletion observed in wells of the second, agreeing with the pore pressure difference model.

On the other hand, we underline that the method developed and the associated workflow can be employed as an auxiliary tool, together with the estimation of water saturation in the assessment of mature fields in the post-salt interval, by operators interested in selecting blocks to optimize and produce the oil remaining in these fields. The ANP resolution No. 749, of September 2018, which reduces the payment of royalties to up to $5 \%$ of the incremental production from mature fields, is one of the stimuli for the operation of these blocks and can make this study an instrument of scientific and commercial interest.

The Marlim field showed a depletion of approximately $0.42 \mathrm{ppg}\left(50.33 \mathrm{~kg} / \mathrm{m}^{3}\right)$ - according to the pore pressure gradient difference model - , reflecting an expected condition since the field is in production since 1991. This depletion (1997-2010) is evaluated as small - around 5\% if considered, hypothetically, a normal initial pore pressure regime, that is, with gradient values of about $8.5 \mathrm{ppg}$ $\left(1,018.52 \mathrm{~kg} / \mathrm{m}^{3}\right)$. This small variation might be associated with an efficient water injection system to maintain the static pressure of the reservoirs in that region of the Marlim field.

\section{ACKNOWLEDGMENTS}

To the Brazilian National Agency of Petroleum, Natural Gas and Biofuels (Agência Nacional do Petróleo, Gás Natural e Biocombustiveis - ANP) for providing the data used in the present study and to all colleagues who helped review this work. To Halliburton for the software used in the performance of the study and for allowing the first author to do the Master's course of the Graduate Program in Geology at the Universidade Federal do Rio de Janeiro (UFRJ). We also thank two anonymous reviewers for their criticisms and suggestions that contributed to the quality of this article.

\section{REFERENCES}

Bampi, D., Costa, O. J. (2010). Marlin Field: an optimization study for a mature field. SPE Latin American and Caribbean Petroleum Engineering Conference, OTC-22994-MS. Lima: SPE. https://doi.org/10.2118/139376-MS

Denney, D. (2012). Marlim Field: Mature-Field Optimization. Journal of Petroleum Technology, 64(1), 82-83. https://doi. org/10.2118/0112-0082-JPT

Duarte, O. O. (2003). Dicionário enciclopédico inglêsportuguês de geofísica e geologia. $3^{\mathrm{a}}$ ed. Rio de Janeiro: Sociedade Brasileira de Geofísica.

Eaton, B. A. (1972). The Effect of Overburden Stress on Geopressure Prediction from Well Logs. Journal of Petroleum Technology, 24(8), 929-934. https://doi. org/10.2118/3719-PA

Eaton, B. A. (1975). The equation for geopressure prediction from well logs. $28^{\text {th }}$ Fall Meeting of the Society of Petroleum Engineers of AIME, SPE-5544-MS. Dallas: SPE. https://doi. org/10.2118/5544-MS

Gardner, G. H. F., Gardner, L. W., Gregory, A. R. (1974). Formation velocity and density - the diagnostic basics for stratigraphic traps. Geophysics, 39(6), 770-780. https://doi. org/10.1190/1.1440465

Johann, P. R. S., Sansonowski, R., Oliveira, R., Bampi, D. (2009). 4D seismic in a heavy oil, turbidite reservoir offshore Brazil. The Leading Edge, 28(6), 718-729. https:// doi.org/10.1190/1.3148415

Johann, P. R. S., Thedy, E. A., Gomes, F. A., Schinelli, M. (2006). 4D Seismic in Brazil: experiences in reservoir monitoring. Offshore Technology Conference, OTC18400-MS. Dallas: OTC. https://doi.org/10.4043/18400-MS

Lorenzatto, R. A., Juiniti, R., Gomes, J. A. T., Martins, J. A. (2004). The Marlim Field development: strategies and challenges. Offshore Technology Conference, OTC-16574-MS. Houston: OTC. https://doi.org/10.4043/16574-MS 
Nunes, J. P. P., Santos, M. S., Maciel, N., Davolio, A., Formento, J-L. (2009). Separation of Pressure and Saturation effects using AVO 4D in Marlim Field. 11th International Congress of the Brazilian Geophysical Society, cp-195-00048. Salvador: SBGf. https://doi. org/10.3997/2214-4609-pdb.195.1508 evt 6year 2009

Oliveira, R. M. (2008). The Marlim Field: incorporating 4D seismic in reservoir-management decisions. Journal of Petroleum Technology, 60(4), 52-110. https://doi. org/10.2118/109336-JPT

Oliveira, R. M. Bampi, D., Sansonowski, R. C., Ribeiro Junior, N., Johann, P. R., Ferreira, D. M., Santos, M. S. (2007). Marlim Field: incorporating 4D seismic in the geological model and application in reservoirmanagement decisions. Latin American and Caribbean Petroleum Engineering Conference, SPE-108062-MS. Buenos Aires: SPE. https://doi.org/10.2118/108062-MS

Pelisman, L. G. T., Vicentelli, M. G. C. (2017). Geophysics characterization of Oligocene turbidites and its relationship with synsedimentary fault systems in Marlim oil field - Campos BasinBrazil: seismic and well profile analysis. 15th International Congress of the Brazilian Geophysical Society. Rio de Janeiro: SBGf.

Picolini, J.P., Chang, H. K. (2019). Modelagem de pressões de poros na área central da Bacia de Santos. Geociências, 38(1), 89-102.

Pinto, A. C. C., Guedes, S. S., Bruhn, C. H. L., Gomes, J. A. T., Sá, A. N., Fagundes Netto, J. R. (2001). Marlim complex development: a reservoir engineering overview. Latin American and Caribbean Petroleum Engineering Conference, SPE69438-MS. Buenos Aires: SPE. https://doi.org/10.2118/69438-MS
Rocha, L. A. S., Azevedo, C. T. (2009). Projeto de poços de petróleo: geopressões e assentamento de colunas de revestimento. $2^{\mathrm{a}}$ ed. Rio de Janeiro: Interciência.

Sansonowski, R. C., Macbeth, C. (2008). Quantitative estimation of pressure and saturation changes using $4 \mathrm{D}$ Seismic: a case study in the Marlim Field, Campos Basin, Brazil. 70th EAGE Conference and Exhibition, P326. Roma: EAEG.

Sansonowski, R. C., Oliveira, R. M., Júnior, N. M. S., Bampi, D., Junior, L. F. A. (2007). 4D seismic interpretation in the Marlim field, Campos Basin, offshore Brazil. SEG Annual Meeting, SEG-2007-2872. San Antonio: SEG.

Souza, J. M., Scarton, J. C., Candido, A., Souza Cruz, C. E., Corá, C. A. G. (1989). The Marlim and Albacora fields: geophysical, geological, and reservoir aspects. Offshore Technology Conference, OTC-5894-MS. Houston: OTC. https://doi.org/10.4043/5894-MS

Triggia, A. A., Correia, C. A., Filho, C. V., Xavier, J. A. D., Machado, J. C. V., Thommas, J. E., Rossi, N. C. L., Pitombo, N. E. S., Couvea, P. C. V. M., Carvalho, R. S., Barragan, R. V. (2001). Fundamentos de engenharia de petróleo. $2^{\mathrm{a}} \mathrm{ed}$. Rio de Janeiro: Interciência.

Zhang, J., Zheng, H., Wang, G., Liu, Z., Qi, Y., Huang, Z., Fan, X. (2020). In-situ stresses, abnormal pore pressures and their impacts on the Triassic Xujiahe reservoirs in tectonically active western Sichuan basin. Marine and Petroleum Geology, 122, 104708. https://doi.org/10.1016/j. marpetgeo.2020.104708 